\title{
Effect of service quality on customer loyalty and the mediating role of customer satisfaction: An empirical investigation for the telecom service industry
}

\author{
Atul Kumar \\ Assistant Professor, Dept. of Commerce, PG DAV College, University of Delhi, New Delhi, India \\ *Corresponding Author: \\ Email: atulkumarsingh82@gmail.com
}

\begin{abstract}
Purpose: The main purpose of this study is to examine the effects of Service Quality Dimensions on Customer Satisfaction and Service Loyalty in Telecom Industry.

Design/Methodology/Approach: Service Quality, Customer Satisfaction and Service Loyalty were measured using 5-point Likert scale from the literature. Exploratory Factor Analysis, Confirmatory Factor analysis and Structural Equation Modeling were conducted to examine the effects of Service Quality on Customer Satisfaction and Service Loyalty.

Findings: Not all dimensions of Service Quality affect Customer Satisfaction and Service Loyalty. Only Empathy and Reliability have significant effect on Customer Satisfaction, whereas, Empathy, Assurance, Responsiveness and Tangibility have significant effect on Customer Loyalty. When it comes to mediation, Customer Satisfaction partially mediates between Empathy and Customer Loyalty.

Research Limitation/Implications: The main limitation of the study is that it was confined to the city of Delhi only. India is a big and diverse nation, so the findings of Delhi city cannot be generalized for the entire nation. Secondly, present study focuses only on Telecom Service Industry.

Practical Implication: The findings clearly indicate the dimensions of Service Quality which the practioners has to focus to provide better service quality.
\end{abstract}

Keywords: Service Quality, Customer Satisfaction, Service Loyalty, Indian Telecom Industry.

\section{Introduction}

Indian Telecom Industry has touched new heights as Indian Government has adopted liberal and reformist policy. With the subscriber base of 1.05 billion, India is second only to China as a telecom market in the world ("Telecom Industry in India," 2017). "The telecommunication industry contributes 6.5 percent ( $\$ 140$ billion ) in GDP which is expected to rise to 8.2 percent by 2020 ("Mobile industry to contribute $8.2 \%$ to GDP by 2020: Govt Report: PTI feed, News - India Today," n.d.). With these kind of figures, Indian telecom industry has become one of the fastest growing industries in India. Among the major telecom players operating in Indian markets are Airtel, Reliance Communications, Vodafone, Tata Indicom, Idea Cellular, Jio, BSNL and MTNL etc.

With an intense competition going on, companies are fighting for their share in the market. Over a period, companies have realized that the key to success is in retaining the customers. With current growth rate and intense competition, there was a need to understand the need of the customers and the companies are doing the same. Companies, which offer services, often find it difficult for customers to evaluate services as services are intangible. Heightened competition and deregulation have led many retail firms to look for profitable ways to differentiate their services. Even when customer is satisfied during one encounter with the service provider, it is particularly difficult for the marketers to provide same level of satisfaction as services are heterogeneous in nature (A.P. Parasuraman, Zeithaml, \& Berry, 1988).
The challenge, which today's marketers face, is how to make customers loyal for long-term profit. However, little is known how to make customers loyal (Gremler, Brown, \& others, 1996). Thus, identifying the factors important for customers to be brand loyal for an inservice industry is very critical. Present study has been conducted with reference to telecom industry involving 429 respondents from the city of Delhi.

$21^{\text {st }}$ century is characterized by less of product differentiation between the products/services offered by companies, more demanding customers and cost optimization by companies. In such a scenario, customer loyalty is the key for success in business. According to Edward \& Sahadev (2011) ; Kotler (2010) ; Reichheld \& Schefter (2000), cost of attracting new customers is 5 times more than the cost of retaining old customers. In such a scenario, customer loyalty is the key for the business success.

The purpose of this study is to expand our knowledge by examining the effects of Service Quality Dimensions on Customer Satisfaction and Customer Loyalty. The focus of the study is to identify the mediating role of Customer Satisfaction between Service Quality and Customer Loyalty, if any. 


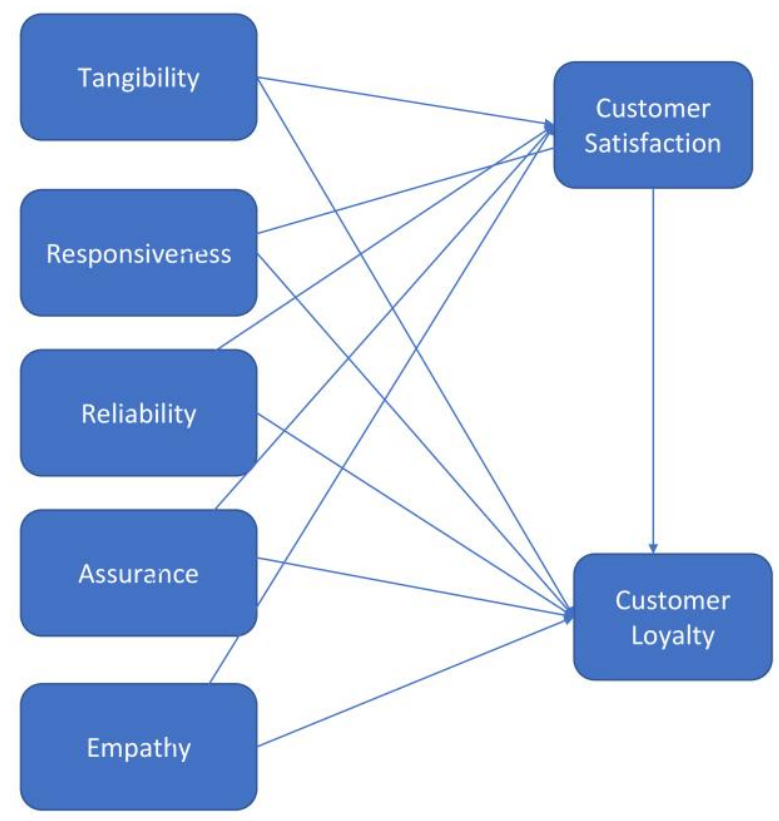

Fig. 1: Proposed Model

\section{Review of Literature}

Oliver (1980) in his theory "Disconfirmation of Expectation" opined that customer is satisfied when expectation matches or performance of the product exceeds the expectation of the customer and dissatisfied when expectations deceed the performance of the customer. According to Zenithal (2017), services are judged based on the beliefs about the service delivery which forms the benchmark. Harr (2008) argued that measuring customer satisfaction can be difficult as customer expectations are formed from the personal experiences of consumption and can be highly personalized.

Harr (2008) criticized the theory of disconfirmation as the theory fails to look into the complexities. There are many factors on which the satisfaction of the customer depends for a particular product. Customer may be satisfied on one aspect and dissatisfied on the other aspect leading to conflict about the overall product.

According to Vargo, Nagao, He \& Morgan (2007), various components of the product effect the customer in different ways.

\section{Service Quality}

Service Quality is the concept of competitiveness and it has generated enough interest in academicians and researchers as it is difficult to define and measure service quality. No clear consensus has been built up on the definition of service quality (Wisniewski, 2001).

Traditionally, service quality has been explained as the gap between customer expectation about the service and perception of how the service has been performed
(A. Parasuraman, Berry, \& Zeithaml, 1991; A. P. Parasuraman et al., 1988). Based on this theory, A.P. Parasuraman et al. (1988) developed SERVQUAL scale consisting of 5 dimensions (tangibility, responsiveness, reliability, assurance and empathy). SERVQUAL measurement was offered as it can be used to explain service quality of any service firm and this led to its vast usage. (Dabholkar, Thorpe \& Rentz, 1996). These researches conclude that gaps can be easily identified once the difference between expectation and perception is figured out (Wang, Lo \& Yang, 2004). However, many researchers have raised questions over the SERVQUAL model. Many researchers have compared SERVPERF model with SERVQUAL and pointed that SERVPERF is a better model (Boulding, Kalra, Staelin, \& Zeithaml, 1993; Cronin \& Taylor, 1992). In response to the criticism of the SERVQUAL model, A. Parasuraman, Zeithaml, \& Berry (1994) have made several key changes to the model. However, for the present study, we have used the old model.

\section{Customer Loyalty}

Customer loyalty is central to many marketing models such as service-profit chain (Anderson \& Mittal, 2000), brand equity (Yoo \& Donthu, 2001), customer equity (Rust, Zeithaml, \& Lemon, 2000) and service recovery (Orsingher, Valentini \& Angelis ,2010). Moreover, service quality and customer satisfaction are predecessor to customer loyalty (Bolton, Kannan, \& Bramlett, 2000; Zeithaml, Berry, \& Parasuraman, 1996). 
Perhaps the most convincing definition of customer loyalty has been given by Oliver (2010). He defined loyalty as "deeply held commitment to rebury or repatronize a preferred product or services consistently in the future, thereby causing repetitive same brand or same brand-set purchasing, despite situational influence and marketing efforts having the potential to cause switching behavior." According to Dick \& Basu (1994), customer loyalty is formed by attitude and behavior components. Loyalty in terms of behavior can be described as the present behavior towards the product of interest (Wolter, Bock, Smith \& Cronin, 2017), whereas, loyalty in terms of attitude can be termed as a behavior to act in a positive way towards loyalty products (Oliver, 1999).

Heskett, Jones, Loveman, Sasser \& Schlesinger (1994) proposed that high quality service is required for customer satisfaction and satisfied customers tend to be loyal customers. Companies can become profitable by having more loyal customers as the loyal customers will decrease the operating cost and overall expenses (Copacino, 1997; Ladhari, Souiden, \& Ladhari, 2011). Many researchers were able to link customer loyalty with the organization success (Rasheed \& Abadi, 2014).

\section{Research Methodology}

Sampling Procedure

515 respondents were surveyed. 86 samples were discarded for response error and only 429 were used for the study. Convenience sampling was used for the present study. Further, data was collected from nonbusiness telecom service users.

Table 1: Demographic Profile of the Respondents

\begin{tabular}{|c|c|c|}
\hline \multicolumn{3}{|l|}{ Age } \\
\hline & $\begin{array}{c}\text { No. of } \\
\text { Respondants } \\
\end{array}$ & $\begin{array}{l}\% \text { of } \\
\text { Total }\end{array}$ \\
\hline $17-26$ & 108 & $25.17 \%$ \\
\hline $27-36$ & 114 & $26.57 \%$ \\
\hline $37-46$ & 106 & $24.71 \%$ \\
\hline $47-56$ & 76 & $17.72 \%$ \\
\hline above 56 & 25 & $5.83 \%$ \\
\hline \multicolumn{3}{|l|}{ Gender } \\
\hline Male & 220 & $51.28 \%$ \\
\hline Female & 209 & $48.72 \%$ \\
\hline
\end{tabular}

\section{Design of Survey Instrument}

The questionnaire was designed in four parts that were associated with Service Quality, Service Loyalty, Customer Satisfaction and Demographic profile of the respondents. Part A consisted of service quality scale. The scale was adopted from A. P. Parasuraman et al. (1988) and suitably modified for the study. Part B consisted of service loyalty scale adopted from Gremler et al. (1996) and was suitably modified. Part C was designed to study customer satisfaction scale and was adopted from Bitner and Hubbert (1994). In Part D, information was gathered about the demographic profile of the respondents.

\section{Analysis}

Variable Tangibility had 2 missing values, Reliability had 8 missing values and Service Loyalty had 11 missing values. Since all above-mentioned variables were measured using 5-point Likert scale, data for the variables was imputed using median.

\section{Exploratory Analysis}

An exploratory factor analysis was conducted on 38 items. Seven factors were extracted with Eigen value $>1$ explaining $67.59 \%$ of variance.

\section{Table 2: KMO and Bartlett Test}

\begin{tabular}{|l|l|r|}
\hline \multicolumn{2}{|l|}{ Kaiser-Meyer-Olkin Measure of } & .923 \\
Sampling Adequacy & \\
\hline Bartlett's Test of & Approx. Chi- & 10213.749 \\
Sphericity & Square & \\
\cline { 2 - 3 } & df & 703 \\
\cline { 2 - 3 } & Sig. & .000 \\
\hline
\end{tabular}

Kaiser Meyer Olkin (KMO) and Bartlett test was used to verify the appropriateness of Factor Analysis. KMO value greater than .80 is considered meritorious (Hair, Black, Babin, \& Anderson, 2010). From Table 2, it can be seen that value of KMO is acceptable. Bartlett test confirmed the correlation among the variable $(\mathrm{p}<.05)$, required for factor analysis.

Further items were subjected to Principal Component Analysis (PCA) with varimax rotation. Seven factors were extracted with Eigen value $>1$ explaining $67.59 \%$ of variance.

Table 3: Factor Loadings

\begin{tabular}{|l|l|c|c|}
\hline S. No & \multicolumn{1}{|c|}{ Dimension } & Loading & $\begin{array}{c}\text { Cronback } \\
\text { alfa }\end{array}$ \\
\hline \multicolumn{2}{|l|}{ Service Loyalty } & \multirow{2}{*}{0.933} \\
\cline { 1 - 2 } 1 & $\begin{array}{l}\text { Believe my present telecom service provider } \\
\text { is a good service provider }\end{array}$ & .747 & \\
\cline { 1 - 3 } 2 & $\begin{array}{l}\text { Seldom consider switching away from present } \\
\text { telecom service provider }\end{array}$ & .726 & \\
\hline
\end{tabular}




\begin{tabular}{|c|c|c|c|}
\hline 3 & $\begin{array}{l}\text { My first choice when I need my present } \\
\text { telecom service provider }\end{array}$ & .726 & \\
\hline 4 & $\begin{array}{l}\text { Doubt that I would switch to another telecom } \\
\text { service provider }\end{array}$ & .725 & \\
\hline 5 & $\begin{array}{l}\text { Try to use present telecom service provider } \\
\text { every time I need services }\end{array}$ & .701 & \\
\hline 6 & $\begin{array}{l}\text { To me, my present telecom service provider is } \\
\text { clearly best to do business with }\end{array}$ & .699 & \\
\hline 7 & $\begin{array}{l}\text { Encourage friends and relatives to do business } \\
\text { with my present telecom service provider }\end{array}$ & .687 & \\
\hline 8 & $\begin{array}{l}\text { Consider my present telecom service provider } \\
\text { as my primary service provider }\end{array}$ & .686 & \\
\hline 9 & $\begin{array}{l}\text { Say positive things about the service of my } \\
\text { telecom service provider to other people }\end{array}$ & .681 & \\
\hline 10 & $\begin{array}{l}\text { Really like doing business with my present } \\
\text { telecom service provider }\end{array}$ & .678 & \\
\hline 11 & $\begin{array}{l}\text { Primary place where I consider when I want } \\
\text { to use my present telecom service provider. }\end{array}$ & .672 & \\
\hline 12 & $\begin{array}{l}\text { Intent to continue doing business with present } \\
\text { telecom service provider. }\end{array}$ & .656 & \\
\hline \multicolumn{4}{|c|}{ Empathy } \\
\hline 1 & $\begin{array}{l}\text { It is unrealistic to expect employees to know } \\
\text { what the need of their customers are. }\end{array}$ & .827 & \multirow{5}{*}{0.885} \\
\hline 2 & $\begin{array}{l}\text { They shouldn't be expected to have opening } \\
\text { hours convenient to all their customers }\end{array}$ & .811 & \\
\hline 3 & $\begin{array}{l}\text { These firms should not be expected to give } \\
\text { customers individual attention. }\end{array}$ & .809 & \\
\hline 4 & $\begin{array}{l}\text { Employees of these firm cannot be expected } \\
\text { to give customer personal attention }\end{array}$ & .808 & \\
\hline 5 & $\begin{array}{l}\text { It is unrealistic to expect these firms to have } \\
\text { their customer's best interest at heart }\end{array}$ & .763 & \\
\hline \multicolumn{4}{|c|}{ Assurance } \\
\hline 1 & $\begin{array}{l}\text { Customers should be able to feel safe in their } \\
\text { transactions with these firm employees. }\end{array}$ & .825 & \multirow{4}{*}{0.94} \\
\hline 2 & $\begin{array}{l}\text { Their employees should get adequate support } \\
\text { from these firms to do their job well. }\end{array}$ & .816 & \\
\hline 3 & $\begin{array}{l}\text { Customers should be able to trust employees } \\
\text { of these firms. }\end{array}$ & .792 & \\
\hline 4 & Their employees should be polite. & .771 & \\
\hline \multicolumn{4}{|c|}{ Reliability } \\
\hline 1 & These firms should be dependable. & .823 & \multirow{5}{*}{0.826} \\
\hline 2 & $\begin{array}{l}\text { When customers have problems, these firms } \\
\text { should be sympathetic and reassuring. }\end{array}$ & .804 & \\
\hline 3 & $\begin{array}{l}\text { They should provide their services at a time } \\
\text { they promise to do so }\end{array}$ & .775 & \\
\hline 4 & $\begin{array}{l}\text { When these firms promise to do something by } \\
\text { a certain time, they should do so }\end{array}$ & .723 & \\
\hline 5 & They should keep their records accurately. & .606 & \\
\hline \multicolumn{4}{|c|}{ Customer Satisfaction } \\
\hline 1 & $\begin{array}{l}\text { Compared to other telecom service provider } \\
\text { you have done business with the present } \\
\text { telecom is better }\end{array}$ & .795 & \multirow{4}{*}{0.854} \\
\hline 2 & $\begin{array}{l}\text { Based on all my experiences, I am not } \\
\text { satisfied. }\end{array}$ & .765 & \\
\hline 3 & In general, I am satisfied & .762 & \\
\hline 4 & $\begin{array}{l}\text { Based on all your experiences, how satisfied } \\
\text { overall are you. }\end{array}$ & .748 & \\
\hline
\end{tabular}




\begin{tabular}{|c|c|c|c|}
\hline \multicolumn{4}{|c|}{ Responsiveness } \\
\hline 1 & $\begin{array}{l}\text { It is not realistic for customers to expect } \\
\text { prompt service from employees of these } \\
\text { firms. }\end{array}$ & .832 & \multirow{4}{*}{0.839} \\
\hline 2 & $\begin{array}{l}\text { They should not be expected to tell the } \\
\text { customers exactly when the services will be } \\
\text { performed. }\end{array}$ & .804 & \\
\hline 3 & $\begin{array}{l}\text { Their employees do not always have to be } \\
\text { willing to help customers. }\end{array}$ & .749 & \\
\hline 4 & $\begin{array}{l}\text { It is okay if they are too busy to respond to } \\
\text { customers request promptly. }\end{array}$ & .741 & \\
\hline \multicolumn{4}{|c|}{ Tangibility } \\
\hline 1 & $\begin{array}{l}\text { Their physical facilities should be visually } \\
\text { appealing }\end{array}$ & .838 & \multirow{4}{*}{0.816} \\
\hline 2 & $\begin{array}{l}\text { Their employees should be well dressed and } \\
\text { appear neat }\end{array}$ & .801 & \\
\hline 3 & $\begin{array}{l}\text { The appearance of the physical facilities of } \\
\text { these firms should be in keeping with the type } \\
\text { of service provided. }\end{array}$ & .787 & \\
\hline 4 & They should have up-to-date equipment. & .738 & \\
\hline
\end{tabular}

\section{Reliability}

Cronback alfa is used to measure the consistency of the scale. Cronback alfa value of greater than .7 is acceptable (Hair, Black, Babin, \& Anderson, 2010). From the Table 3, it can be seen that cronback alfa values were greater than .7 for all the constructs.

\section{Validity}

Content Validity

Content Validity is used to measure the degree by which the elements represent the construct. For the present study, content validity was ensured as service quality dimensions, service loyalty dimensions and customer satisfaction dimensions were identified from literature and were examined by experts and academicians.

\section{Convergent Validity}

Convergent validity can be identified with the help of factor loading. If factor loading is greater than or $=.07$, then sufficient convergent validity is demonstrated (Hair, Black, Babin, \& Anderson, 2010). All factor loading was higher than .7 signifying sufficient convergent validity.

\section{Discriminant Validity}

It is the extent to which constructs are distinct from other constructs (Hair, Black, Babin, \& Anderson, 2010). The correlation between the factor was less than .7 showing sufficient discriminant validity and there were no cross loadings.

\section{Confirmatory Factor Analysis}

Confirmatory Factor Analysis was conducted. All values were in the accepted range. However, value of Root Mean Square Error of Approximation (RMSEA) which is recommended to be below .50 was exactly .50. No treatment was given to improve the model as the value is very close to the recommended level.

\section{Table 4: Model Fit}

\begin{tabular}{|l|c|c|}
\hline \multicolumn{1}{|c|}{ Metric } & Observed Value & Recommended \\
\hline CMIN/DF & 2.310 & $1-3$ \\
\hline CFI & .926 & $>.95$ \\
\hline GFI & .851 & $<.80$ \\
\hline RMSEA & .051 & $<.50$ \\
\hline
\end{tabular}

The value of CFI was below 0.95. The value of RMSEA was 0.51 and the desirable value is below 0.5. However, both values were close to the recommended value and, therefore, no treatment was given to data.

\section{Validity and Reliability}


To test convergent validity, value of AVE was calculated for each construct. All values of AVE were above 0.50

To test discriminant validity, following conditions should be met:

1. Average Variance Explained (AVE) >Maximum Shared Variance (MSV)

2. Average Variance Explained (AVE) $>$ Average Shared Variance (ASV)

For all the constructs, both conditions were met and there was no issue of discriminant validity. Composite reliability was also tested and it was found to be above .7 for all the constructs.

\section{Hypothesis}

H1: Service Quality has a positive effect on Customer Satisfaction.

H1a: Empathy has a positive effect on Customer Satisfaction.

H1b: Reliability has a positive effect on Customer Satisfaction.

H1c: Assurance has a positive effect on Customer Satisfaction.

H1d: Responsiveness has a positive effect on Customer Satisfaction.

H1e: Tangibility has a positive effect on Customer Satisfaction.

H2: Service Quality has a positive effect on Service Loyalty.

H2a: Empathy has a positive effect on Service Loyalty.

H2b: Reliability has a positive effect on Service Loyalty.

H2c: Assurance has a positive effect on Service Loyalty.

H2d: Responsiveness has a positive effect on Service Loyalty.

H2e: Tangibility has a positive effect on Service Loyalty.

H3: Customer Satisfaction has a positive effect on Service Loyalty.

H4: Customer Satisfaction positively and fully mediates the positive relationship between Service Quality and Service Loyalty.

\section{Structural Model}

Figure 2: Structural Model

\section{Hypothesis Testing}

Table 5: Hypothesis

\begin{tabular}{|l|c|c|}
\hline \multicolumn{1}{|c|}{ Hypothesis } & Evidence & Conclusion \\
\hline $\begin{array}{l}\text { H1a: Empathy has a positive effect on } \\
\text { Customer Satisfaction. }\end{array}$ & $\mathrm{Beta}=.169$ & Supported \\
\hline $\begin{array}{l}\text { H1b: Reliability has a positive effect on } \\
\text { Customer Satisfaction. }\end{array}$ & $\mathrm{Beta}=-.1800$ & Supported \\
\hline $\begin{array}{l}\text { H1c: Assurance has a positive effect on } \\
\text { Customer Satisfaction. }\end{array}$ & $\mathrm{P}=.000$ & \\
\hline $\begin{array}{l}\text { H1d: Responsiveness has a positive }=.102 \\
\text { effect on Customer Satisfaction. }\end{array}$ & $\mathrm{P}=.103$ & Not supported \\
\hline $\begin{array}{l}\text { H1e: Tangibility has a positive effect on }=.013 \\
\text { Customer Satisfaction. }\end{array}$ & $\mathrm{P}=.805$ & Not supported \\
\hline
\end{tabular}




\begin{tabular}{|l|c|c|}
\hline $\begin{array}{l}\text { H2a: Empathy has a positive effect on } \\
\text { Service Loyalty. }\end{array}$ & $\begin{array}{c}\text { Beta }=.000 \\
\mathrm{p}=.000\end{array}$ & Supported \\
\hline $\begin{array}{l}\text { H2b: Reliability has a positive effect on } \\
\text { Service Loyalty. }\end{array}$ & $\begin{array}{c}\text { Beta }=.000 \\
\mathrm{p}=.993\end{array}$ & Not supported \\
\hline $\begin{array}{l}\text { H2c: Assurance has a positive effect on } \\
\text { Service Loyalty. }\end{array}$ & $\begin{array}{c}\mathrm{Beta}=.478 \\
\mathrm{p}=.000\end{array}$ & Supported \\
\hline $\begin{array}{l}\text { H2d: Responsiveness has a positive } \\
\text { effect on Service Loyalty. }\end{array}$ & $\begin{array}{c}\mathrm{Beta}=.093 \\
\mathrm{p}=.001\end{array}$ & Supported \\
\hline $\begin{array}{l}\text { H2e: Tangibility has a positive effect on } \\
\text { Service Loyalty. }\end{array}$ & $\begin{array}{c}\text { Beta }=.063 \\
\mathrm{p}=.011\end{array}$ & Supported \\
\hline $\begin{array}{l}\text { H3: Satisfaction has a positive effect on } \\
\text { Loyalty }\end{array}$ & $\begin{array}{c}\text { Beta }=.525 \\
\mathrm{p}=.000\end{array}$ & Supported \\
\hline $\begin{array}{l}\text { H4: Satisfaction positively mediates } \\
\text { Empathy and Loyalty }\end{array}$ & $\begin{array}{c}\text { Standardized } \\
\text { indirect effect: .156 } \\
\mathrm{P}=.001\end{array}$ & Partial \\
\hline
\end{tabular}

\section{Mediation Model}

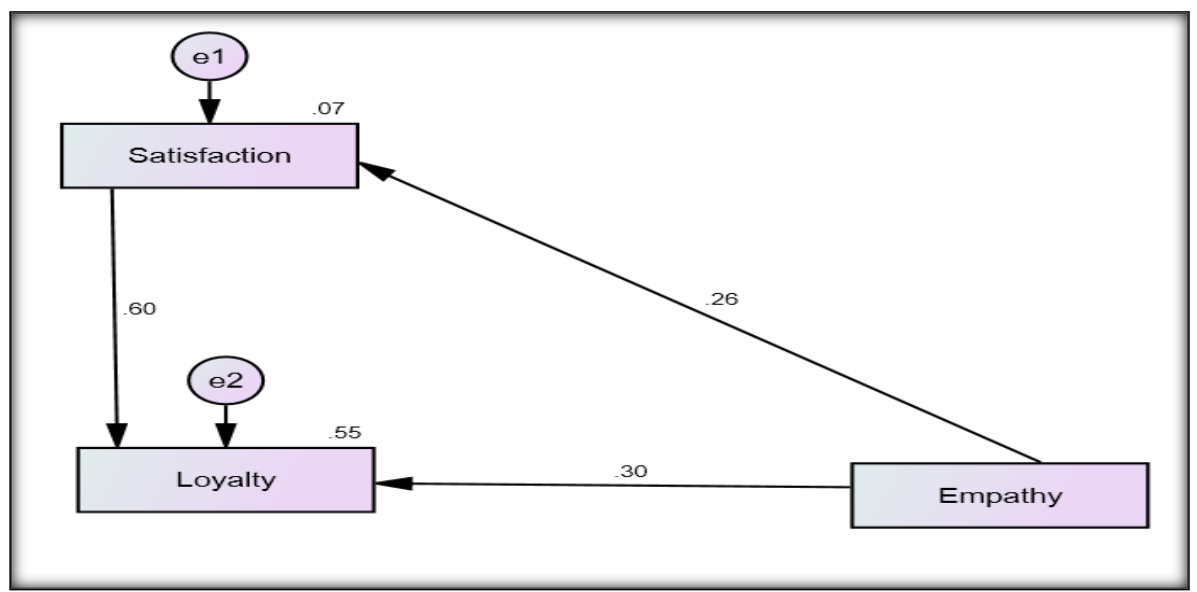

\section{Figure 3: Mediation Model}

In absence of mediator i.e. "Satisfaction", effect of Empathy on Loyalty was tested and was found to be significant, beta $=.454, \mathrm{p}<.05$. Indirect effect was checked in presence of mediator and was found to be significant beta $=.156, \mathrm{p}<.05$. Since the relationship between Empathy and Loyalty was significant even in the presence of mediator, it was considered to be a case of partial mediation.

\section{Conclusion}

The present study was conducted to find out the relationship of service quality dimensions on Customer Satisfaction and Service Loyalty in the Indian Telecom Industry. The present study highlights that although service quality is made up of five dimensions. However, when it comes to Indian Telecom Industry, not all dimensions affect customer satisfaction and Service Loyalty. Only Empathy and Reliability have significant effect on Customer Satisfaction, whereas, Empathy, Assurance, Responsiveness and Tangibility have significant effect on Customer loyalty. When it comes to mediation, Customer Satisfaction partially mediates between Empathy and Customer Loyalty. The present study clearly highlights the dimensions on which the practitioner needs to focus while trying to serve customers.

Many researchers have criticized SERVQUAL scale. In spite of all the criticism, SERVQUAL scale remains the most used scale in the area of service industry. Future researches in the same field can focus on SERVPF scale, which has been projected as a substitute to the SERVQUAL scale. Apart from using SERVPERF scale, Indian service industry in on the rise and there are sectors other than the telecom which need to be studied in detail.

\section{References}

1. Anderson, E. W., \& Mittal, V. (2000). Strengthening the Satisfaction-Profit Chain. Journal of Service Research, 3(2), 107-120. https://doi.org/10.1177/109467050032001.

2. Bolton, R. N., Kannan, P. K., \& Bramlett, M. D. (2000). Implications of loyalty program membership and service experiences for customer retention and value. Journal of the Academy of Marketing Science, 28(1), 95-108. https://doi.org/10.1177/0092070300281009

3. Boulding, W., Kalra, A., Staelin, R., \& Zeithaml, V. A. (1993). A Dynamic Process Model of Service Quality: 
From Expectations to Behavioral Intentions. Journal of Marketing Research, 30(1), 7-27. https://doi.org/10.2307/3172510

4. Copacino, W. C. (1997). Supply Chain Management: The Basics and Beyond (1 edition). Boca Raton, Fla. : Falls Church, Va: CRC Press.

5. Cronin, J. J., \& Taylor, S. A. (1992). Measuring Service Quality: A Reexamination and Extension. Journal of Marketing, 56(3), 55-68. https://doi.org/10.2307/1252296

6. Dabholkar, P. A., Thorpe, D. I., \& Rentz, J. O. (1996). A measure of service quality for retail stores: Scale development and validation. Journal of the Academy of Marketing Science, 24(1), 3. https://doi.org/10.1007/BF02893933

7. Dick, A. S., \& Basu, K. (1994). Customer loyalty: Toward an integrated conceptual framework. Journal of the Academy of Marketing Science, 22(2), 99-113. https://doi.org/10.1177/0092070394222001.

8. Edward, M., \& Sahadev, S. (2011). Role of switching costs in the service quality, perceived value, customer satisfaction and customer retention linkage. Asia Pacific Journal of Marketing and Logistics, 23(3), 327-45. https://doi.org/10.1108/13555851111143240

9. Gremler, D. D., Brown, S. W., \& others. (1996). Service loyalty: its nature, importance, and implications. Advancing Service Quality: A Global Perspective, 5, 171-81.

10. Harr, K. K. (2008). Service dimensions of service quality impacting customer satisfaction of fine dining restaurants in Singapore. UNLV Theses, Dissertations, Professional Papers, and Capstones. Retrieved from http://digitalscholarship.unlv.edu/thesesdissertations/686

11. Heskett, J. L., Jones, T. O., Loveman, G. W., Sasser, W. E., \& Schlesinger, L. A. (1994). Putting the Service-Profit Chain to Work. Retrieved from http://www.hbs.edu/faculty/Pages/item.aspx?num=9149

12. Kotler. (2010). Principles of Marketing 13th Edition a South Asian Perspective (13th edition). New Delhi: Pearson.

13. Ladhari, R., Souiden, N., \& Ladhari, I. (2011). Determinants of loyalty and recommendation: The role of perceived service quality, emotional satisfaction and image. Journal of Financial Services Marketing, 16(2), 111-24. https://doi.org/10.1057/fsm.2011.10

14. Mobile industry to contribute $8.2 \%$ to GDP by 2020 : Govt report : PTI feed, News - India Today. (n.d.). Retrieved January 1, 2018, from http://indiatoday.intoday.in/story/mobile-industry-tocontribute-8.2percent-to-gdp-by-2020-govtreport/1/819553.html

15. Oliver, R. L. (1980). A Cognitive Model of the Antecedents and Consequences of Satisfaction Decisions. Journal of Marketing Research, 17(4), 460-469. https://doi.org/10.2307/3150499

16. Oliver, R. L. (1999). Whence Consumer Loyalty? Journal of Marketing, 63, 33-44. https://doi.org/10.2307/1252099

17. Oliver, R. L. (2010). Satisfaction: A Behavioral Perspective on the Consumer (2 edition). Armonk, N.Y: Routledge.

18. Orsingher, C., Valentini, S., \& Angelis, M. de. (2010). A meta-analysis of satisfaction with complaint handling in services. Journal of the Academy of Marketing Science, 38(2), 169-186. https://doi.org/10.1007/s11747-0090155-Z

19. Parasuraman, A., Berry, L. L., \& Zeithaml, V. A. (1991). Perceived service quality as a customer-based performance measure: An empirical examination of organizational barriers using an extended service quality model. Human Resource Management, 30(3), 335-364. https://doi.org/10.1002/hrm.3930300304

20. Parasuraman, A. P., Zeithaml, V., \& Berry, L. (1988). SERVQUAL: A multiple- Item Scale for measuring consumer perceptions of service quality.

21. Parasuraman, A., Zeithaml, V. A., \& Berry, L. L. (1994). Alternative scales for measuring service quality: A comparative assessment based on psychometric and diagnostic criteria. Journal of Retailing, 70(3), 201-30. https://doi.org/10.1016/0022-4359(94)90033-7

22. Rasheed, F. A., \& Abadi, M. F. (2014). Impact of Service Quality, Trust and Perceived Value on Customer Loyalty in Malaysia Services Industries. Procedia - Social and Behavioral Sciences, 164(Supplement C), 298-304. https://doi.org/10.1016/j.sbspro.2014.11.080

23. Reichheld, F. F., \& Schefter, P. (2000, July 1). E-Loyalty: Your Secret Weapon on the Web. Retrieved October 1, 2017, from https://hbr.org/2000/07/e-loyalty-your-secretweapon-on-the-web

24. Rust, R., Zeithaml, V., \& Lemon, K. (2000). Driving Customer Equity: How Customer Lifetime Value is Reshaping Corporate Strategy (First Printing edition). New York: Free Press.

25. Telecom Industry in India. (2017). [www.ibef.org]. Retrieved January 10, 2017, from https://www.ibef.org/industry/telecommunications.aspx

26. Vargo, S. L., Nagao, K., He, Y., \& Morgan, F. W. (2007) Satisfiers, Dissatisfiers, Criticals, and Neutrals: A Review of Their Relative Effects on Customer (Dis)satisfaction. Academy of Marketing Science Review. Retrieved from https://www.questia.com/library/journal/1G1177719438/satisfiers-dissatisfiers-criticals-and-neutrals

27. Wang, Y., Lo, H.-P., \& Yang, Y. (2004). An Integrated Framework for Service Quality, Customer Value, Satisfaction: Evidence from China's Telecommunication Industry. Information Systems Frontiers, 6(4), 325-40. https://doi.org/10.1023/B:ISFI.0000046375.72726.67

28. Wisniewski, M. (2001). Using SERVQUAL to assess customer satisfaction with public sector services. Managing Service Quality: An International Journal, 11(6), 380-388. https://doi.org/10.1108/EUM0000000006279

29. Wolter, J. S., Bock, D., Smith, J. S., \& Cronin, J. J. (2017). Creating Ultimate Customer Loyalty Through Loyalty Conviction and Customer-Company Identification. Journal of Retailing. https://doi.org/10.1016/j.jretai.2017.08.004

30. Yoo, B., \& Donthu, N. (2001). Developing and validating a multidimensional consumer-based brand equity scale. Journal of Business Research, 52(1), 1-14. https://doi.org/10.1016/S0148-2963(99)00098-3

31. Zeihthaml. (2017). Services Marketing: Integrating Customer Focus Across the Firm (Sixth edition). Chennai, India: McGraw Hill Education.

32. Zeithaml, V. A., Berry, L. L., \& Parasuraman, A. (1996). The Behavioral Consequences of Service Quality. Journal of Marketing, 60(2), 31-46. https://doi.org/10.2307/1251929 